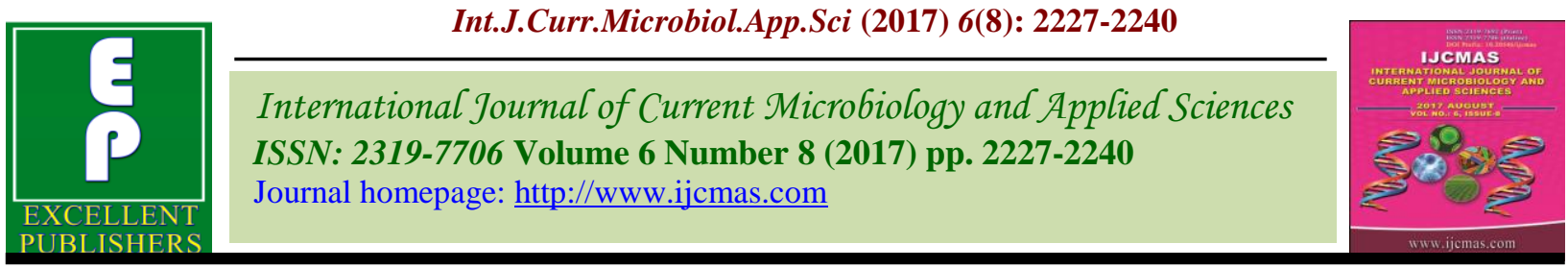

Original Research Article

https://doi.org/10.20546/ijcmas.2017.608.262

\title{
Effect of Different Nitrogen Levels on Morpho Physiological and Yield Parameters in Rice (Oryza sativa L.)
}

\author{
K. Rajesh*, Ramesh Thatikunta ${ }^{1}$, D. Saida Naik ${ }^{1}$ and J. Arunakumari ${ }^{2}$ \\ ${ }^{1}$ Department of Crop Physiology, ${ }^{2}$ Department of Biochemistry, College of Agriculture, \\ Professor Jayashankar Telangana State Agricultural University, Hyderabad-30, Telangana, India \\ *Corresponding author
}

A B S T R A C T

\begin{tabular}{|c|c|}
\hline Keywords & \multirow{4}{*}{$\begin{array}{l}\text { Field experiment was conducted during } 2011-12 \text { to study the response of rice varieties on } \\
\text { morpho-physiological and yield under two nitrogen levels } 120 \mathrm{~kg} \mathrm{~N} \mathrm{ha}^{-1}[\mathrm{~N} 120], 60 \mathrm{~kg} \mathrm{~N} \\
\mathrm{ha}^{-1} \text { [N60] as main treatments and twenty six rice genotypes as sub treatments. In the } \\
\text { present investigation among the nitrogen treatments application of } 120 \mathrm{~kg} \mathrm{~N} \mathrm{ha}^{-1} \text { recorded } \\
\text { significantly higher values for morpho-physiological parameters such as number of tillers } \\
\mathrm{hill}^{-1} \text {, SCMR values, photosynthetic rate and also resulted in maximum number of panicles } \\
\text { hill }{ }^{-1} \text {, number of filled grains hill }{ }^{-1} \text {, filled grain percentage, } 1000 \text { grain weight and grain } \\
\text { yield. Spikelet sterility and number of unfilled grains hill }{ }^{-1} \text { were minimum in this } \\
\text { treatment. Among the genotypes, MTU-1001 recorded the maximum grain yield of } 5021 \\
\mathrm{~kg} \mathrm{ha}^{-1} \text { even under application of } 60 \mathrm{~kg} \mathrm{~N} \mathrm{ha}{ }^{-1} \text {. This indicated that maximum yield can be } \\
\text { attributed to maximum SCMR values, more photosynthetic rate, more tillers and panicles, } \\
\text { more number of grains hill }{ }^{-1} \text {, maximum filled grain percentage and minimum spikelet } \\
\text { sterility. }\end{array}$} \\
\hline $\begin{array}{l}\text { Rice varieties, } \\
\text { Morphological } \\
\text { parameters, } \\
\text { Physiological } \\
\text { parameters and } \\
\text { Yield. }\end{array}$ & \\
\hline Article Info & \\
\hline & \\
\hline
\end{tabular}

Introduction

Rice (Oryza sativa L.) is staple food for more than $60 \%$ of the global population and forms the cheapest source of food and energy. Nitrogen $(\mathrm{N})$ is the indispensable nutrient to rice production and its uptakes is affected by rice varieties, environment, soil conditions, crop rotations etc. Managing nitrogen fertilization in rice fields is a challenging task for farmers because of various kinds of losses due to de -nitrification, deep percolation and run-off in flooded soils resulting in low nitrogen use efficiency. While excessive nitrogen promotes lodging and diseases and results in low nitrogen use efficiency, low application of nitrogen will often reduce rice. Among the various factors contributing for rice production, fertilizers play an important role. Use of adequate nitrogen rate is important not only for obtaining maximum economic returns, but also to reduce environmental pollution. Excessive nitrogen application can result in accumulation of large amounts of post-harvest residual soil nitrogen. Residual soil nitrate $\left(\mathrm{NO}^{-3}\right)$ may be available for subsequent crops in the next season, but such nitrogen is highly susceptible to leaching during non-crop periods (Sachiko et al., 2009).

Rice varieties may respond differently to nitrogen application. Cultivars selected under high nitrogen fertilizer application may not be 
suitable for soils with low nitrogen status. Even after the application of high rates of fertilizer nitrogen to rice, expected yield levels might not be obtained. If plant nitrogen status can be increased without lodging or increasing the incidence of disease, a significant increase in yield requires increased sink capacity, maintenance of high leaf nitrogen content and a longer grain filling duration. Rice varieties differ in their ability to extract soil and fertilizer nitrogen and in its distribution to different plant organs. Understanding nitrogen uptake and assimilation is necessary in any attempt to optimize the efficiency of absorbed nitrogen for grain production. Hassan et al., (2007) showed that vigorous biomass accumulation could lead to dilution of plant nitrogen content up to the panicle initiation stage, which could lead to inefficient use of nitrogen for spikelet formation. It is important to increase the efficiency of soil and fertilizer nitrogen by using nutrient efficient varieties. The present investigation was to assess variability in grain yield, and morpho physiological parameters of rice varieties under optimal and suboptimal nitrogen levels.

\section{Materials and Methods}

A field experiment was conducted during 2011-12 at Collage Farm, College of Agriculture, Professor Jayashankar Telangana State Agricultural University, Rajendranagar, Hyderabad. The experiment was laid out in a split plot design with two nitrogen levels i.e., Optimum of $120 \mathrm{~kg} \mathrm{~N} \mathrm{ha}{ }^{-1}$ [N120], Sub optimal of $60 \mathrm{~kg} \mathrm{~N} \mathrm{ha}^{-1}$ [N60] as main treatments and twenty six rice genotypes as sub treatments and the experiment was replicated thrice. The rice genotypes were sown separately in raised bed nursery and thirty day old seedlings were transplanted into $6 \mathrm{~m}^{2}(2 \mathrm{~m} \times 3 \mathrm{~m})$ plots by adopting a spacing of $20 \mathrm{~cm}$ between rows and $15 \mathrm{~cm}$ between plants with in a row. Nitrogen was applied as per the treatments $60 \mathrm{Kg} \mathrm{N} \mathrm{ha}^{-1}$ and $120 \mathrm{~kg} \mathrm{~N}$ $\mathrm{ha}^{-1}$ in three equal splits in the form of urea. Depending on the nitrogen treatments one third dose of nitrogen was applied as basal dose at the time of planting of the crop. Remaining two equal splits of nitrogen was broadcasted at maximum tillering and panicle initiation stages. Phosphorus was applied at the rate of $60 \mathrm{~kg} \mathrm{P}_{2} \mathrm{O}_{5} \mathrm{ha}^{-1}$ in the form of single super phosphate and potassium $40 \mathrm{~kg}$ $\mathrm{K}_{2} \mathrm{O} \mathrm{ha}{ }^{-1}$ in the form of muriate of potash was applied as basal dose at the time of transplanting. Irrigation and weed management was done in time to time. The border rows were harvested first and then, the net plot area was harvested and the produce was threshed by beating on a threshing bench, cleaned and sun dried to 14 percent moisture level. Plants in one $\mathrm{m}^{2}$ area were tagged separately.

The number of both ear bearing and non ear bearing tillers per hill were counted at the time of harvest and reported as tiller number per hill. At harvest the tillers bearing panicles per hill were counted and expressed as number of effective tillers per hill. Number of days from sowing to the day when primary panicles in 50 percent of the plants in each plot and each replication were in heading was recorded. Number of days required from sowing to the yellowing of the leaves and stem (symptoms of maturity) in each plot and each replication was recorded and reported as days to maturity in different treatments.

For analysis of physiological characters, five plants in each plot were tagged and observations at maximum tillering, flowering and maturity stages were recorded. The SPAD (Soil Plant Analytical Development) chlorophyll meter readings measures the greenness or relative chlorophyll content of leaves. This meter enables to obtain instant readings without destroying the plant tissue. The third leaf from top was used for 
measuring SCMR, which was taken midway between the leaf base and tip. Mean of five values from five hills was at maximum tillering, flowering and maturity stages were recorded. Photosynthetic rate measurements were recorded at maximum tillering, flowering and maturity stages by using (IRGA- Infra Red Gas Analyser) portable photosynthetic measurement system from leaves that had fully expanded recently. During measurements, the PAR (Photosynthetically Active Radiation) was kept at $1200 \mu \mathrm{mol} \mathrm{m} \mathrm{m}^{-2} \mathrm{~s}^{-1}$. The $\mathrm{CO}_{2}$ concentration was kept at $387 \pm 6 \mathrm{ppm}$. These measurements were made between 10.00 am to 12.00 noon at all the sampling dates and expressed as $\mu \mathrm{mol} \mathrm{CO} \mathrm{CO}_{2} \mathrm{~m}^{-1}$. Grain from net plot area was thoroughly sun dried, threshed, cleaned and weight of grains was recorded and expressed in yield per hectare. The data were analyzed statistically following the method given by Panse and Sukhatme (1978) and wherever the results were significant, the critical difference (CD) was calculated at 5 per cent level of significance $(\mathrm{P}=0.05)$.

\section{Results and Discussion}

\section{Morphological characters}

\section{Number of tillers hill ${ }^{-1}$}

Number of tillers per unit area is the most important component of yield. More the number of tillers, especially fertile tillers; the more will be the yield. Nitrogen deficiency led to reduction in the number of tillers as well as in the number of productive tillers which in turn had a negative effect on dry matter production and yield (Sandya Rani, 2012).

Data on number of tillers hill ${ }^{-1}$ is presented in table 1. Between the treatments, there was significant increase in number of tillers. With increase in nitrogen application 12.6 to 14.9 with a mean of 13.7 tillers hill $^{-1}$ were recorded. Application of nitrogen at $120 \mathrm{~kg} \mathrm{~N}$ $\mathrm{ha}^{-1}$ has resulted in maximum number of tillers $\operatorname{hill}^{-1}(14.9)$, while at $60 \mathrm{~kg} \mathrm{~N} \mathrm{ha}{ }^{-1}$ minimum tillers hill $^{-1}$ (12.6) were recorded. Among the genotypes the number of tillers ranged from 12.2 to 16.2 with a mean of 13.7 tillers hill $^{-1}$. MTU-1001 recorded maximum number of 16.2 tillers hill $^{-1}$ followed by MTU-1010 (15.6 tillers hill ${ }^{-1}$ ). Minimum number of 12.2 tillers $^{-1}$ hill $^{-1}$ was recorded in Varalu. The differences among the genotypes for this parameter are statistically significant.

Interaction between nitrogen levels and rice genotypes was found to be significant for number of tillers hill ${ }^{-1}$. Among the genotypes MTU-1001 recorded maximum number of tillers hill ${ }^{-1}$ both in $120 \mathrm{~kg} \mathrm{~N}^{-1}$ (18 tillers hill $^{-1}$ ) and $60 \mathrm{~kg} \mathrm{~N} \mathrm{ha}^{-1}$ (14.3 tillers hill ${ }^{-1}$. The minimum number of tillers hill ${ }^{-1}$ were recorded in the genotypes Varalu and JGL3855 which recorded 13 tillers hill ${ }^{-1}$ at $120 \mathrm{~kg}$ $\mathrm{N} \mathrm{ha}^{-1}$ and Varalu, Chittimutyalu and Divya 11.3 tillers hill $^{-1}$ at $60 \mathrm{~kg} \mathrm{~N} \mathrm{ha}^{-1}$.

Application of optimum nitrogen $(120 \mathrm{~kg} \mathrm{~N}$ $\mathrm{ha}^{-1}$ ) during grand vegetative stage has induced more number of tillers $\mathrm{m}^{-2}$ as observed by the Devi and Sumathi (2011). The increase in tillers hill ${ }^{-1}$ was reported with increase in nitrogen levels upto $120 \mathrm{~kg} \mathrm{~N} \mathrm{ha}^{-1}$, $150 \mathrm{~kg} \mathrm{~N} \mathrm{ha}^{-1}$ and $175 \mathrm{~kg} \mathrm{~N}^{-1}$ (Ramesh et al., 2009).

\section{Time of heading (50\% plants with heads)}

Data pertaining to time taken for heading as influenced by nitrogen supply in rice genotypes is presented in table 2 . The time of heading got delayed with increase in nitrogen levels from 60 to $120 \mathrm{~kg} \mathrm{~N} \mathrm{ha}^{-1}$. The time taken for heading in $120 \mathrm{~kg} \mathrm{~N} \mathrm{ha}^{-1}$ is 87 day as against 84 day in $60 \mathrm{~kg} \mathrm{~N} \mathrm{ha}^{-1}$. Abundant supply of nitrogen $\left(150 \mathrm{~kg} \mathrm{~N} \mathrm{ha}^{-1}\right)$ might have delayed the vegetative growth and shifted the 
balance between vegetative and reproductive growth, leading to delay in days to $50 \%$ heading.

There was significant difference in number of days taken for time of heading in the genotypes studied. Among rice genotypes, Varalu was earliest (67 day) while BPT-5204 was late (95 day) with a genotypic mean of 86 days. Zahid et al., (2009) reported highly significant variation among genotypes for days to 50 percent heading and attributed this to the genetic makeup of exotic lines and genotypic environmental interaction. Days to $50 \%$ heading is an important parameter as it is positively and significantly correlated with seed yield per plant in rice crop (Ashrafuzzaman et al., 2009). The interaction between nitrogen levels and genotypes for time of heading was non significant.

\section{Days to maturity}

Data on days taken for maturity is presented in table 2 and there was significant increase in the number of days taken for maturity with increase in nitrogen application from $60 \mathrm{~kg} \mathrm{~N}$ ha $^{-1}$ (123 day) to $120 \mathrm{~kg} \mathrm{~N} \mathrm{ha}^{-1}$ (128 day). Among the genotypes there was significant difference in number of days taken for maturity which ranged from 97-140 with a genotypic mean of 126 days. BPT-5204 has taken maximum days for maturity (140 days), while it was lower in Varalu (97 days). There was a non significant interaction effect between nitrogen levels and genotypes for days to maturity.

Karim et al., (2007) studied rice genotypes for variability and genetic parameter analysis and reported that such variation for days to maturity was due to genetic constituent rather than environment. Shahidullah et al., (2009) concluded that the wide variation in phenological characters depends on genotypic constituent, micro and macro environments.

\section{Physiological characters}

\section{SPAD chlorophyll meter reading (SCMR)}

The role of chlorophyll in photosynthesis is well established but the relationship between chlorophyll content and rate of photosynthesis is equivocal. Data on SCMR as influenced by nitrogen application in rice genotypes is presented in table 3. SCMR values increased from maximum tillering stage (37.8) to flowering stage (42.5) and thereafter declined towards maturity (32.5). There was significant increase in SCMR values due to nitrogen application. Among the treatments, application of $120 \mathrm{~kg} \mathrm{~N} \mathrm{ha}^{-1}$ has resulted in mean SCMR values of 38.4 at maximum tillering stage which increased to 43.4 at flowering stage and reduced to 33.8 at maturity stage. Plants which were grown in $60 \mathrm{~kg} \mathrm{~N} \mathrm{ha}{ }^{-1}$ recorded the minimum SCMR values at all the stages.

The interaction between $\mathrm{N}$ levels and genotypes at maximum tillering stage was not significant. SCMR value was maximum in MTU-1001 both at flowering stage (45.1) and at maturity stage (35.4), while minimum values were recorded in Varalu at flowering (40.5) and maturity stages (29.7). It was earlier reported that genotypes maintained high chlorophyll content from panicle initiation stage to grain filling stage, which is more important in determining grain yield (Ranjitha 2011 and Thakur et al., 2011). The interaction between treatments and genotypes was significant at flowering and maturity stages. Among the genotypes MTU-1001 recorded maximum SCMR values at flowering stage in $120 \mathrm{~kg} \mathrm{~N} \mathrm{ha}^{-1}$ (47.4) and 60 $\mathrm{kg} \mathrm{N}^{-1}$ (43.2). The minimum SCMR values were observed in Varalu at N 120 (41.2) and at N 60 (39.8) treatments. Similarly at maturity stage the maximum SCMR values were recorded by the genotype MTU-1001 in $120 \mathrm{~kg} \mathrm{~N} \mathrm{ha}^{-1}$ (36.1) and $60 \mathrm{~kg} \mathrm{~N} \mathrm{ha}^{-1}$ (34.6). 
The minimum SCMR values were observed in Varalu at $120 \mathrm{~kg} \mathrm{~N} \mathrm{ha}^{-1}(30.6)$ and at $60 \mathrm{~kg}$ $\mathrm{N}$ ha $^{-1}$ (28.8). The chlorophyll meter quantifies the greenness or relative chlorophyll content of leaves. Critical or threshold SPAD value is important and it indicates the leaf area based critical nitrogen concentration in rice leaves. These results are in agreement with Swain et al., (2006) who found highly significant and positive relation between total chlorophyll content at all the growth stages and grain number $\mathrm{m}^{-2}$, indicating the role of chlorophyll content in sink development and grain filling, leading to higher productivity.

\section{Photosynthetic rate $\left(\mu \mathrm{mol} \mathrm{CO}_{2} \mathrm{~m}^{-2} \mathrm{~s}^{-1}\right)$}

Nitrogen nutrition influences the content of photosynthetic pigments, synthesis of the enzymes taking part in the carbon reduction, formation of the membrane system of chloroplasts, etc. Thus the increase in growth and yield owing to the application of $\mathrm{N}$ fertilizers may be attributed to the fact that these nutrients being important constituents of nucleotides, proteins, chlorophyll and enzymes, involve in various metabolic processes which have direct impact on vegetative and reproductive phases of plants.

Data on photosynthetic rate shows that there was an increase in the values from maximum tillering (18.41 $\left.\mu \mathrm{mol} \quad \mathrm{CO}_{2} \quad \mathrm{~m}^{-2} \mathrm{~s}^{-1}\right)$ to flowering stage $\left(22.24 \mu \mathrm{mol} \mathrm{CO} \mathrm{Cm}^{-2} \mathrm{~s}^{-1}\right)$ and recorded a decrease thereafter towards maturity stage $\left(13.23 \mu \mathrm{mol} \mathrm{CO}_{2} \mathrm{~m}^{-2} \mathrm{~s}^{-1}\right)$ (Table 4). Significant increase in leaf photosynthetic rate was recorded due to nitrogen application. Nitrogen application at $120 \mathrm{~kg} \mathrm{~N} \mathrm{ha}^{-1}$ has resulted in mean leaf photosynthetic rate of $19.47 \mu \mathrm{mol} \mathrm{CO} \mathrm{m}^{-2} \mathrm{~s}^{-1}$ at maximum tillering stage which increased to $23.43 \mu \mathrm{mol} \mathrm{CO} \mathrm{m}^{-2} \mathrm{~s}^{-1}$ at flowering stage and decreased to $13.63 \mu \mathrm{mol} \mathrm{CO}_{2} \mathrm{~m}^{-2} \mathrm{~s}^{-1}$ by maturity stage. Photosynthetic rate recorded was low at all the stages when nitrogen fertilizers were applied at $60 \mathrm{~kg} \mathrm{~N} \mathrm{ha}^{-1}$. Nitrogen application directly increased the chlorophyll content and leaf surface area which is turn increased photosynthetic process in rice. Similar results were reported by Hassan et al., (2007) who suggested that low levels of nitrogen can reduce photosynthetic rate as well as leaf chlorophyll content and photosynthetic efficiency. Significant differences were observed between the genotypes in photosynthetic rate at maximum tillering and flowering stage, but the differences were non significant at maturity stage. At maximum tillering stage, photosynthetic rate ranged from $16.84 \mu \mathrm{mol}$ $\mathrm{CO}_{2} \mathrm{~m}^{-2} \mathrm{~s}^{-1}$ to $19.44 \mu \mathrm{mol} \mathrm{CO} \mathrm{m}^{-2} \mathrm{~s}^{-1}$, at flowering stage from $20.49 \mu \mathrm{mol} \mathrm{CO} \mathrm{m}^{-2} \mathrm{~s}^{-1}$ to $23.14 \mu \mathrm{mol} \mathrm{CO} \mathrm{Cm}^{-2} \mathrm{~s}^{-1}$. The minimum values were recorded in Divya at maximum tillering (16.84) and flowering stages (20.49). While, maximum values were recorded in MTU-1001 at both maximum tillering and flowering stages $\left(19.44\right.$ and $23.14 \mu \mathrm{mol} \mathrm{CO}_{2}$ $\mathrm{m}^{-2} \mathrm{~s}^{-1}$ respectively).

Genotypes that maintain higher leaf chlorophyll content during crop growth period may be considered as potential donors for the ability to produce higher photosynthetic rate (Miah et al., 1997). The interaction effects between nitrogen levels and genotypes for photosynthetic rate were non significant at all the crop growth stages.

\section{Yield and yield attributes}

The yield ultimately depends on the better expression of yield attributing characters like panicle number hill ${ }^{-1}$, number of filled grains and unfilled grains panicle ${ }^{-1}, 1000$ grain weight and yield.

\section{Panicle number hill ${ }^{-1}$}

The data pertaining to panicle number hill ${ }^{-1}$ as influenced by nitrogen in rice genotypes is 
presented in table 5. The number of panicles hill $^{-1}$ increased significantly with increase in $\mathrm{N}$ application from $60 \mathrm{~kg} \mathrm{~N}^{-1}$ (11.7) to 120 $\mathrm{kg} \mathrm{N} \mathrm{ha}{ }^{-1}$ (13.5). Increase in panicle number with increase in nitrogen application in rice was earlier reported by Gosh et al., (2013). Among the genotypes, the number of panicle hill $^{-1}$ ranged from 11.5 to 14.5 with a mean of 12.6 panicles hill $^{-1}$ and the difference were statistically significant. The genotype MTU1001 (14.5) recorded maximum number of panicles hill ${ }^{-1}$ which was on par with MTU1010 (14.0), BPT-5204 (13.7). While the minimum number of panicles hill $^{-1}$ was recorded in Varalu (11.5).

The interaction between treatments and genotypes was non significant, with respect to this parameter. In rice, number of panicles per unit area is primary yield determining component. For achieving higher yield in rice, the sink size should be increased by increasing panicle size or number or either. The cultivar having large panicles may be the best option but the adequate numbers of panicles need to be maintained properly in terms of sink-source balance (Miah et al., 1997, Kim et al., 1993).

\section{Number of filled grains hill ${ }^{-1}$}

The data on number of filled grains hill $^{-1}$ revealed that there was significant increase in this parameter with increase in nitrogen application which ranged from 1039 (N 60) to 1290 (N120) with a mean of 1165 filled grains hill ${ }^{-1}$ (Table 5). Such increase in filled grains per panicle with increase in $\mathrm{N}$ fertilizers up to $200 \mathrm{~kg} \mathrm{~N} \mathrm{ha}^{-1}$ was reported by Sharma and Masand (2008). Among the genotype MTU-1001 recorded maximum value of 1507 filled grains hill ${ }^{-1}$ followed by MTU-1010 (1447 filled grains hill ${ }^{-1}$ ) while minimum filled grains hill $^{-1}$ of 840 was recorded in genotype Erramallelu. The differences among the genotypes for this parameter are statistically significant.
Interaction between nitrogen levels and rice genotypes was significant for number of filled grains hill ${ }^{-1}$ which ranged from 647 to 1586 . Among the genotypes MTU-1001 recorded maximum number of filled grains hill $^{-1}$ both in N 120 (1586) and N 60 (1428) treatments. Whereas minimum number of filled grains hill $^{-1}$ were recorded in genotype Erramallelu in $120 \mathrm{~kg} \mathrm{~N} \mathrm{ha}^{-1}$ (1032) and $60 \mathrm{~kg} \mathrm{~N}^{-1}$ (647). Samonte et al., (1998) found that number of filled grains per panicle had significant positive effect on rice grain yield. Similar results were reported by Sowmya (2008) and Suryaprabha et al., (2011).

\section{Number of unfilled grains hill'-1}

Data on unfilled grains hill ${ }^{-1}$ as influenced by nitrogen supply in rice genotypes is presented in table 5. Significant differences were noticed between the treatments and increase in nitrogen level reduced the unfilled grains hill $^{-1}$ from 449 to 573 . Unfilled grains hill ${ }^{-1}$ was minimum with application of $120 \mathrm{~kg} \mathrm{~N}$ $\mathrm{ha}^{-1}$ (449) and maximum number of unfilled grains hill ${ }^{-1}$ was recorded at $60 \mathrm{~kg} \mathrm{~N} \mathrm{ha}{ }^{-1}$ (573). Among the rice genotypes there was significant difference in number of unfilled grains hill $^{-1}$ which ranged from 429 to 641 with a mean of 511. Minimum number of unfilled grains hill $^{-1}$ was recorded in MTU1001 (429) where as maximum number of unfilled grains hill $^{-1}$ was recorded in Kavya (641). Interaction between nitrogen levels and rice genotypes was statistically significant. Number of unfilled grains hill ${ }^{-1}$ which ranged from 374 to 756 . Among the interactions minimum number of unfilled grains hill $^{-1}$ were recorded at $120 \mathrm{~kg} \mathrm{~N} \mathrm{ha}^{-1}$ (374) in genotype MTU-1001 where as maximum number of unfilled grains hill ${ }^{-1}$ was recorded at $60 \mathrm{~kg} \mathrm{~N} \mathrm{ha}^{-1}$ (756) in WGL-32100.

\section{Grain yield (kg ha-1)}

Nitrogen is the most essential element that determines the yield potential of intensified 
agricultural system. Additional doses of nitrogen are usually applied to increase grain yield. A perusal of the data on grain yield indicates that with increased nitrogen levels there was significant increase in the grain yield (Table 6). Highest grain yield of 4591 $\mathrm{kg} \mathrm{ha}{ }^{-1}$ was recorded with $120 \mathrm{Kg} \mathrm{N}$ ha ${ }^{1}$.While lowest grains yield of $3985 \mathrm{~kg} \mathrm{ha}^{-1}$ was recorded with $60 \mathrm{Kg} \mathrm{N}^{-1}$ treatment. There was significant difference in grain yield of various rice genotypes studied. Among the genotypes MTU-1001 has recorded maximum grain yield of $5192 \mathrm{~kg} \mathrm{ha}^{-1}$, while the lowest grain yield of $2912 \mathrm{~kg} \mathrm{ha}^{-1}$ was recorded in Varalu

Table. 1 The influence of nitrogen on number of tillers hill ${ }^{-1}$ in rice genotypes during kharif-2011

\begin{tabular}{|l|c|c|c|}
\hline \multirow{2}{*}{\multicolumn{1}{|c|}{ Genotypes }} & \multicolumn{3}{|c|}{ Number of tillers hill $^{-1}$} \\
\cline { 2 - 4 } & $\mathbf{6 0 ~ k g ~ N ~ h a ~}^{-1}$ & $\mathbf{1 2 0} \mathbf{~ k g ~ N ~ h a ~}^{-1}$ & Mean \\
\hline WGL-14 & 12.0 & 14.0 & 13.0 \\
\hline BPT-5204 & 14.0 & 15.0 & 14.5 \\
\hline WGL-2395 & 12.7 & 14.0 & 13.2 \\
\hline Divya & 11.3 & 14.3 & 12.8 \\
\hline JGL-11727 & 11.7 & 14.0 & 12.8 \\
\hline Pothana & 13.3 & 14.0 & 13.7 \\
\hline RNR-C-28 & 13.3 & 15.7 & 14.5 \\
\hline RNR-2354 & 13.0 & 15.3 & 14.2 \\
\hline RNR-2465 & 11.7 & 15.3 & 13.5 \\
\hline JGL-3855 & 13.7 & 13.0 & 13.3 \\
\hline NDLR-7 & 12.7 & 15.0 & 13.8 \\
\hline Surekha & 12.3 & 16.0 & 14.2 \\
\hline RNR-2458 & 12.3 & 13.7 & 13.0 \\
\hline MTU-1001 & 14.3 & 18.0 & 16.2 \\
\hline Erramallelu & 12.0 & 13.7 & 12.8 \\
\hline Bhadrakali & 14.0 & 14.3 & 14.2 \\
\hline JGL-1798 & 14.0 & 15.0 & 14.5 \\
\hline Godavari isukalu & 13.3 & 15.3 & 14.3 \\
\hline Kavya & 11.7 & 15.0 & 13.3 \\
\hline MTU-1010 & 14.0 & 17.3 & 15.7 \\
\hline Chittimutyalu & 11.3 & 15.3 & 13.3 \\
\hline WGL-32100 & 12.7 & 16.3 & 14.5 \\
\hline Varalu & 11.3 & 13.0 & 12.2 \\
\hline JGL-1470 & 12.3 & 15.7 & 14.0 \\
\hline JGL-3844 & 11.7 & 14.0 & 12.8 \\
\hline JGL-3828 & 12.0 & 14.0 & 13.0 \\
\hline Mean & 12.6 & 14.9 & 13.7 \\
\hline \multirow{2}{*}{ C.D } & & 0.340 & \\
\cline { 2 - 4 } (5\%) Genotypes (G) & & 1.015 & \\
\hline \multicolumn{1}{|c|}{ T X G } & & 1.436 & \\
\hline
\end{tabular}


Table.2 The influence of nitrogen on days to $50 \%$ heading and maturity in rice genotypes during kharif-2011

\begin{tabular}{|c|c|c|c|c|c|c|c|}
\hline \multirow{2}{*}{\multicolumn{2}{|c|}{ Genotypes }} & \multicolumn{3}{|c|}{ Days to $50 \%$ heading } & \multicolumn{3}{|c|}{ Days to maturity } \\
\hline & & $60 \mathrm{~kg} \mathrm{~N} \mathrm{ha}^{-1}$ & $120 \mathrm{~kg} \mathrm{~N} \mathrm{ha}^{-1}$ & Mean & $60 \mathrm{~kg} \mathrm{~N} \mathrm{ha}{ }^{-1}$ & $120 \mathrm{~kg} \mathrm{~N} \mathrm{ha}^{-1}$ & Mean \\
\hline \multicolumn{2}{|c|}{ WGL-14 } & 88 & 92 & 90 & 126 & 128 & 127 \\
\hline \multicolumn{2}{|c|}{ BPT-5204 } & 93 & 96 & 95 & 137 & 142 & 140 \\
\hline \multicolumn{2}{|c|}{ WGL-2395 } & 84 & 87 & 85 & 120 & 126 & 123 \\
\hline \multicolumn{2}{|c|}{ Divya } & 82 & 85 & 83 & 122 & 126 & 124 \\
\hline \multicolumn{2}{|c|}{ JGL-11727 } & 89 & 92 & 91 & 121 & 128 & 125 \\
\hline \multicolumn{2}{|c|}{ Pothana } & 81 & 85 & 83 & 120 & 122 & 121 \\
\hline \multicolumn{2}{|c|}{ RNR-C-28 } & 81 & 84 & 83 & 121 & 123 & 122 \\
\hline \multicolumn{2}{|c|}{ RNR-2354 } & 83 & 86 & 85 & 126 & 132 & 129 \\
\hline \multicolumn{2}{|c|}{ RNR-2465 } & 81 & 85 & 83 & 126 & 130 & 128 \\
\hline \multicolumn{2}{|c|}{ JGL-3855 } & 82 & 85 & 84 & 120 & 126 & 123 \\
\hline \multicolumn{2}{|c|}{ NDLR-7 } & 88 & 92 & 90 & 126 & 130 & 128 \\
\hline \multicolumn{2}{|c|}{ Surekha } & 88 & 91 & 90 & 126 & 134 & 130 \\
\hline \multicolumn{2}{|c|}{ RNR-2458 } & 84 & 87 & 86 & 124 & 127 & 125 \\
\hline \multicolumn{2}{|c|}{ MTU-1001 } & 87 & 90 & 89 & 126 & 132 & 129 \\
\hline \multicolumn{2}{|c|}{ Erramallelu } & 81 & 84 & 82 & 120 & 124 & 122 \\
\hline \multicolumn{2}{|c|}{ Bhadrakali } & 85 & 88 & 87 & 126 & 132 & 129 \\
\hline \multicolumn{2}{|c|}{ JGL-1798 } & 81 & 84 & 83 & 122 & 127 & 125 \\
\hline \multicolumn{2}{|c|}{ Godavari isukalu } & 80 & 83 & 82 & 120 & 125 & 123 \\
\hline \multicolumn{2}{|c|}{ Kavya } & 88 & 92 & 90 & 129 & 133 & 131 \\
\hline \multicolumn{2}{|c|}{ MTU-1010 } & 90 & 93 & 92 & 126 & 132 & 129 \\
\hline \multicolumn{2}{|c|}{ Chittimutyalu } & 79 & 82 & 81 & 120 & 122 & 121 \\
\hline \multicolumn{2}{|c|}{ WGL-32100 } & 88 & 92 & 90 & 128 & 133 & 131 \\
\hline \multicolumn{2}{|c|}{ Varalu } & 65 & 68 & 67 & 95 & 98 & 97 \\
\hline \multicolumn{2}{|c|}{ JGL-1470 } & 83 & 86 & 85 & 123 & 127 & 125 \\
\hline \multicolumn{2}{|c|}{ JGL-3844 } & 89 & 91 & 90 & 126 & 133 & 129 \\
\hline \multicolumn{2}{|c|}{ JGL-3828 } & 88 & 92 & 90 & 128 & 135 & 132 \\
\hline Mean & & 84 & 87 & 86 & 123 & 128 & 126 \\
\hline C.D & $\begin{array}{c}\text { Treatments } \\
\text { (T) }\end{array}$ & & 1.794 & & & 1.624 & \\
\hline$(5 \%)$ & $\begin{array}{l}\text { Genotypes } \\
\text { (G) }\end{array}$ & & 2.097 & & & 2.310 & \\
\hline & TX G & & NS & & & NS & \\
\hline
\end{tabular}


Table.3 The influence of nitrogen on SCMR values in rice genotypes at different stages of crop during kharif-2011

\begin{tabular}{|c|c|c|c|c|c|c|c|c|c|c|}
\hline \multirow{2}{*}{\multicolumn{2}{|c|}{ Genotypes }} & \multicolumn{3}{|c|}{ At maximum tillering stage } & \multicolumn{3}{|c|}{ At flowering stage } & \multicolumn{3}{|c|}{ At maturity stage } \\
\hline & & $60 \mathrm{~kg} \mathrm{~N} \mathrm{ha}^{-1}$ & $120 \mathrm{~kg} \mathrm{~N} \mathrm{ha}^{-1}$ & Mean & $60 \mathrm{~kg} \mathrm{~N} \mathrm{ha}^{-1}$ & $120 \mathrm{~kg} \mathrm{~N} \mathrm{ha}^{-1}$ & Mean & $60 \mathrm{~kg} \mathrm{~N} \mathrm{ha}^{-1}$ & $120 \mathrm{~kg} \mathrm{~N} \mathrm{ha}^{-1}$ & Mean \\
\hline \multicolumn{2}{|c|}{ WGL-14 } & 36.5 & 38.5 & 37.5 & 40.5 & 41.6 & 41.1 & 30.1 & 34.8 & 32.5 \\
\hline \multicolumn{2}{|c|}{ BPT-5204 } & 37.0 & 39.5 & 38.2 & 41.6 & 43.8 & 42.7 & 32.5 & 35.1 & 33.8 \\
\hline \multicolumn{2}{|c|}{ Divya } & 37.7 & 39.4 & 38.6 & 40.4 & 41.5 & 41.0 & 31.3 & 32.1 & 31.7 \\
\hline \multicolumn{2}{|c|}{ JGL-11727 } & 37.8 & 39.1 & 38.4 & 41.7 & 46.8 & 44.3 & 32.4 & 33.5 & 32.9 \\
\hline \multicolumn{2}{|c|}{ Pothana } & 36.9 & 38.7 & 37.8 & 41.0 & 42.7 & 41.9 & 31.3 & 34.4 & 32.9 \\
\hline \multicolumn{2}{|c|}{ RNR-C-28 } & 37.5 & 38.6 & 38.0 & 41.4 & 43.7 & 42.6 & 31.6 & 34.4 & 33.0 \\
\hline \multicolumn{2}{|c|}{ RNR-2354 } & 35.9 & 37.2 & 36.5 & 42.5 & 45.4 & 44.0 & 31.9 & 34.7 & 33.3 \\
\hline \multicolumn{2}{|c|}{ RNR-2465 } & 36.0 & 38.0 & 37.0 & 40.8 & 41.1 & 40.9 & 31.0 & 31.4 & 31.2 \\
\hline \multicolumn{2}{|c|}{ JGL-3855 } & 38.9 & 37.5 & 38.2 & 42.9 & 44.8 & 43.9 & 32.1 & 36.1 & 34.1 \\
\hline \multicolumn{2}{|c|}{ NDLR-7 } & 37.2 & 38.7 & 37.9 & 42.9 & 44.2 & 43.6 & 31.1 & 34.5 & 32.8 \\
\hline \multicolumn{2}{|c|}{ Surekha } & 38.1 & 39.1 & 38.6 & 42.9 & 42.7 & 42.8 & 29.5 & 31.9 & 30.7 \\
\hline \multicolumn{2}{|c|}{ RNR-2458 } & 37.0 & 38.8 & 37.9 & 42.4 & 43.4 & 42.9 & 31.6 & 33.5 & 32.6 \\
\hline \multicolumn{2}{|c|}{ MTU-1001 } & 37.8 & 40.9 & 39.3 & 43.2 & 47.4 & 45.1 & 34.6 & 36.1 & 35.4 \\
\hline \multicolumn{2}{|c|}{ Erramallelu } & 36.7 & 38.0 & 37.4 & 40.3 & 40.9 & 40.6 & 29.4 & 31.3 & 30.4 \\
\hline \multicolumn{2}{|c|}{ JGL-1798 } & 36.7 & 38.4 & 37.6 & 41.3 & 43.1 & 42.2 & 32.3 & 33.8 & 33.1 \\
\hline \multicolumn{2}{|c|}{ Godavari isukalu } & 38.6 & 38.8 & 38.7 & 41.1 & 42.8 & 41.9 & 30.7 & 32.8 & 31.7 \\
\hline \multicolumn{2}{|c|}{ Kavya } & 37.2 & 38.3 & 37.8 & 42.5 & 44.7 & 43.6 & 30.6 & 34.5 & 32.6 \\
\hline \multicolumn{2}{|c|}{ MTU-1010 } & 37.3 & 39.5 & 38.4 & 42.4 & 45.1 & 43.8 & 32.8 & 35.8 & 34.3 \\
\hline \multicolumn{2}{|c|}{ Chittimutyalu } & 37.2 & 38.8 & 38.0 & 41.4 & 42.9 & 42.1 & 29.2 & 32.8 & 31.0 \\
\hline \multicolumn{2}{|c|}{ WGL-32100 } & 36.1 & 37.7 & 36.9 & 41.2 & 44.2 & 42.7 & 32.4 & 35.3 & 33.9 \\
\hline \multicolumn{2}{|c|}{ Varalu } & 35.4 & 36.3 & 35.9 & 39.8 & 41.2 & 40.5 & 28.8 & 30.6 & 29.7 \\
\hline \multicolumn{2}{|c|}{ JGL-1470 } & 37.3 & 38.1 & 37.7 & 41.6 & 43.6 & 42.6 & 31.1 & 33.6 & 32.4 \\
\hline JGL-3 & & 36.6 & 37.8 & 37.2 & 40.4 & 42.1 & 41.3 & 30.2 & 32.7 & 31.5 \\
\hline GL-38 & & 35.9 & 36.3 & 36.1 & 41.1 & 43.3 & 42.2 & 30.0 & 33.9 & 32.0 \\
\hline Mean & & 37.1 & 38.4 & 37.8 & 41.5 & 43.4 & 42.5 & 31.2 & 33.8 & 32.5 \\
\hline & Treatments (T) & & 1.225 & & & 0.671 & & & 1.251 & \\
\hline C.D & Genotypes (G) & & NS & & & 1.251 & & & 0.888 & \\
\hline$(5 \%)$ & T X G & & NS & & & 1.825 & & & 1.642 & \\
\hline
\end{tabular}


Table.4 The influence of nitrogen on photosynthetic rate $\left(\mu \mathrm{mol} \mathrm{CO}_{2} \mathrm{~m}^{-2} \mathrm{~s}^{-1}\right)$ in rice genotypes at different stages of crop during kharif-2011

\begin{tabular}{|c|c|c|c|c|c|c|c|c|c|c|}
\hline \multirow{2}{*}{\multicolumn{2}{|c|}{ Genotypes }} & \multicolumn{3}{|c|}{ At maximum tillering stage } & \multicolumn{3}{|c|}{$\begin{array}{l}\text { At flowering stage } \\
\end{array}$} & \multicolumn{3}{|c|}{ At maturity stage } \\
\hline & & $60 \mathrm{~kg} \mathrm{~N} \mathrm{ha}^{-1}$ & $\begin{array}{c}120 \mathrm{~kg} \mathrm{~N} \\
\mathrm{ha}^{-1}\end{array}$ & Mean & $\begin{array}{c}60 \mathrm{~kg} \mathrm{~N} \\
\mathrm{ha}^{-1} \\
\end{array}$ & $\begin{array}{c}120 \mathrm{~kg} \mathrm{~N} \\
\mathrm{ha}^{-1}\end{array}$ & Mean & $\begin{array}{c}60 \mathrm{~kg} \mathrm{~N}^{-1} \mathrm{~N} \\
\mathrm{ha}^{-1}\end{array}$ & $\begin{array}{c}120 \text { kg N } \\
\text { ha }^{-1}\end{array}$ & Mean \\
\hline \multicolumn{2}{|c|}{ WGL-14 } & 18.33 & 19.09 & 18.71 & 21.57 & 23.10 & 22.33 & 12.44 & 14.46 & 13.45 \\
\hline \multicolumn{2}{|c|}{ BPT-5204 } & 16.58 & 19.16 & 17.87 & 20.65 & 23.51 & 22.08 & 11.94 & 14.31 & 13.12 \\
\hline \multicolumn{2}{|c|}{ WGL-2395 } & 17.31 & 19.85 & 18.58 & 20.74 & 23.84 & 22.29 & 12.65 & 13.31 & 12.98 \\
\hline \multicolumn{2}{|c|}{ Divya } & 16.27 & 17.40 & 16.84 & 19.54 & 21.43 & 20.49 & 12.20 & 14.20 & 13.20 \\
\hline \multicolumn{2}{|c|}{ JGL-11727 } & 16.80 & 19.88 & 18.34 & 20.94 & 23.94 & 22.44 & 11.27 & 14.67 & 12.97 \\
\hline \multicolumn{2}{|c|}{ Pothana } & 16.11 & 18.76 & 17.44 & 20.35 & 22.86 & 21.61 & 12.88 & 14.23 & 13.56 \\
\hline \multicolumn{2}{|c|}{ RNR-C-28 } & 17.02 & 17.77 & 17.39 & 20.96 & 21.86 & 21.41 & 12.20 & 12.75 & 12.48 \\
\hline \multicolumn{2}{|c|}{ RNR-2354 } & 18.16 & 19.00 & 18.58 & 21.55 & 23.09 & 22.32 & 14.33 & 14.03 & 14.18 \\
\hline \multicolumn{2}{|c|}{ RNR-2465 } & 16.35 & 19.60 & 17.97 & 19.86 & 23.43 & 21.65 & 14.82 & 14.62 & 14.72 \\
\hline \multicolumn{2}{|c|}{ JGL-3855 } & 17.49 & 20.18 & 18.83 & 21.55 & 24.03 & 22.79 & 12.70 & 14.36 & 13.53 \\
\hline \multicolumn{2}{|c|}{ NDLR-7 } & 17.65 & 20.03 & 18.84 & 21.60 & 23.73 & 22.67 & 14.02 & 12.52 & 13.27 \\
\hline \multicolumn{2}{|c|}{ Surekha } & 17.35 & 18.73 & 18.04 & 21.31 & 22.69 & 22.00 & 13.00 & 13.40 & 13.20 \\
\hline \multicolumn{2}{|c|}{ RNR-2458 } & 16.59 & 19.68 & 18.14 & 20.99 & 23.66 & 22.33 & 12.28 & 12.60 & 12.44 \\
\hline \multicolumn{2}{|c|}{ MTU-1001 } & 18.39 & 20.48 & 19.44 & 21.84 & 24.44 & 23.14 & 12.23 & 12.92 & 12.58 \\
\hline \multicolumn{2}{|c|}{ Erramallelu } & 18.64 & 19.00 & 18.82 & 21.47 & 22.74 & 22.11 & 13.70 & 13.77 & 13.73 \\
\hline \multicolumn{2}{|c|}{ Bhadrakali } & 16.08 & 18.60 & 17.34 & 20.12 & 22.80 & 21.46 & 12.93 & 14.55 & 13.74 \\
\hline \multicolumn{2}{|c|}{ JGL-1798 } & 16.37 & 19.11 & 17.74 & 20.42 & 23.46 & 21.94 & 12.79 & 13.43 & 13.11 \\
\hline \multicolumn{2}{|c|}{ Godavari isukalu } & 16.79 & 20.12 & 18.45 & 20.76 & 24.04 & 22.40 & 12.04 & 12.82 & 12.43 \\
\hline \multicolumn{2}{|c|}{ Kavya } & 17.61 & 20.02 & 18.82 & 20.69 & 23.56 & 22.13 & 12.70 & 12.42 & 12.56 \\
\hline \multicolumn{2}{|c|}{ MTU-1010 } & 18.91 & 19.81 & 19.36 & 21.82 & 24.39 & 23.11 & 12.37 & 13.12 & 12.74 \\
\hline \multicolumn{2}{|c|}{ Chittimutyalu } & 16.97 & 20.43 & 18.70 & 20.68 & 23.83 & 22.26 & 11.98 & 13.32 & 12.65 \\
\hline \multicolumn{2}{|c|}{ WGL-32100 } & 18.02 & 20.51 & 19.26 & 21.80 & 24.15 & 22.97 & 13.93 & 13.79 & 13.86 \\
\hline \multicolumn{2}{|c|}{ Varalu } & 18.32 & 19.30 & 18.81 & 21.18 & 23.56 & 22.37 & 12.55 & 13.09 & 12.82 \\
\hline \multicolumn{2}{|c|}{ JGL-1470 } & 17.61 & 20.07 & 18.84 & 21.91 & 23.54 & 22.72 & 14.01 & 13.50 & 13.75 \\
\hline JGL-38 & & 17.51 & 20.32 & 18.92 & 21.60 & 23.78 & 22.69 & 12.65 & 13.27 & 12.96 \\
\hline JGL-38 & & 17.74 & 19.45 & 18.59 & 21.43 & 23.68 & 22.55 & 13.06 & 14.92 & 13.99 \\
\hline Mean & & 17.35 & 19.47 & 18.41 & 21.05 & 23.43 & 22.24 & 12.83 & 13.63 & 13.23 \\
\hline & Treatments (T) & & 0.482 & & & 0.056 & & & 0.362 & \\
\hline (5\%) & Genotypes (G) & & 1.219 & & & 1.196 & & & $\mathrm{NS}$ & \\
\hline$(5 \%)$ & T X G & & NS & & & NS & & & NS & \\
\hline
\end{tabular}


Table.5 The influence of nitrogen on number of panicles hill ${ }^{-1}$, filled and unfilled grains hill ${ }^{-1}$ in rice genotypes during kharif 2011

\begin{tabular}{|c|c|c|c|c|c|c|c|c|c|c|}
\hline \multirow{2}{*}{\multicolumn{2}{|c|}{ Genotypes }} & \multicolumn{3}{|c|}{ No. of panicles hill ${ }^{-1}$} & \multicolumn{3}{|c|}{ No. of filled grains hill ${ }^{-1}$} & \multicolumn{3}{|c|}{ No. of unfilled grains hill-1 } \\
\hline & & $60 \mathrm{~kg} \mathrm{~N} \mathrm{ha}^{-1}$ & $\begin{array}{c}120 \mathrm{~kg} \mathrm{~N}^{-1} \\
\mathrm{ha}^{-1}\end{array}$ & Mean & $\begin{array}{c}60 \mathrm{~kg} \mathrm{~N} \\
\mathrm{ha}^{-1}\end{array}$ & $\begin{array}{c}120 \\
\text { ha }^{-1}\end{array}$ & Mean & $\begin{array}{c}60 \mathrm{~kg} \mathrm{~N}^{-1} \mathrm{~N} \\
\mathrm{ha}^{-1}\end{array}$ & $\begin{array}{c}120 \mathrm{~kg} \mathrm{~N} \\
\mathrm{ha}^{-1}\end{array}$ & Mean \\
\hline \multicolumn{2}{|c|}{ WGL-14 } & 11.7 & 13.0 & 12.3 & 1221 & 1386 & 1304 & 565 & 406 & 485 \\
\hline \multicolumn{2}{|c|}{ BPT-5204 } & 13.0 & 14.3 & 13.7 & 1307 & 1446 & 1376 & 528 & 416 & 472 \\
\hline \multicolumn{2}{|c|}{ WGL-2395 } & 12.0 & 14.0 & 13.0 & 1297 & 1467 & 1382 & 577 & 424 & 501 \\
\hline \multicolumn{2}{|c|}{ Divya } & 12.0 & 14.3 & 13.2 & 990 & 1241 & 1115 & 508 & 417 & 463 \\
\hline \multicolumn{2}{|c|}{ JGL-11727 } & 11.0 & 13.0 & 12.0 & 1024 & 1282 & 1153 & 512 & 446 & 479 \\
\hline \multicolumn{2}{|c|}{ Pothana } & 11.7 & 13.0 & 12.3 & 1113 & 1305 & 1209 & 630 & 468 & 549 \\
\hline \multicolumn{2}{|c|}{ RNR-C-28 } & 12.0 & 14.0 & 13.0 & 1004 & 1147 & 1075 & 611 & 491 & 551 \\
\hline \multicolumn{2}{|c|}{ RNR-2354 } & 11.7 & 14.0 & 12.8 & 919 & 1221 & 1070 & 555 & 475 & 515 \\
\hline \multicolumn{2}{|c|}{ RNR-2465 } & 11.0 & 12.3 & 11.7 & 782 & 1322 & 1052 & 536 & 448 & 492 \\
\hline \multicolumn{2}{|c|}{ JGL-3855 } & 11.7 & 13.0 & 12.3 & 885 & 1154 & 1020 & 488 & 402 & 445 \\
\hline \multicolumn{2}{|c|}{ NDLR-7 } & 11.0 & 13.0 & 12.0 & 939 & 1325 & 1132 & 549 & 457 & 503 \\
\hline \multicolumn{2}{|c|}{ Surekha } & 11.0 & 13.0 & 12.0 & 890 & 1065 & 977 & 543 & 428 & 486 \\
\hline \multicolumn{2}{|c|}{ RNR-2458 } & 11.0 & 12.3 & 11.7 & 1021 & 1217 & 1119 & 517 & 417 & 467 \\
\hline \multicolumn{2}{|c|}{ MTU-1001 } & 13.0 & 16.0 & 14.5 & 1428 & 1586 & 1507 & 484 & 374 & 429 \\
\hline \multicolumn{2}{|c|}{ Erramallelu } & 12.0 & 13.3 & 12.7 & 647 & 1032 & 840 & 498 & 404 & 451 \\
\hline \multicolumn{2}{|c|}{ Bhadrakali } & 12.0 & 13.0 & 12.5 & 1074 & 1290 & 1182 & 646 & 493 & 570 \\
\hline \multicolumn{2}{|c|}{ JGL-1798 } & 12.3 & 13.3 & 12.8 & 1166 & 1357 & 1261 & 611 & 447 & 529 \\
\hline \multicolumn{2}{|c|}{ Godavari isukalu } & 12.0 & 14.0 & 13.0 & 866 & 1172 & 1019 & 679 & 554 & 617 \\
\hline \multicolumn{2}{|c|}{ Kavya } & 11.0 & 13.3 & 12.2 & 1105 & 1314 & 1210 & 734 & 548 & 641 \\
\hline \multicolumn{2}{|c|}{ MTU-1010 } & 13.0 & 15.0 & 14.0 & 1387 & 1507 & 1447 & 509 & 396 & 452 \\
\hline \multicolumn{2}{|c|}{ Chittimutyalu } & 11.3 & 13.3 & 12.3 & 917 & 1275 & 1096 & 667 & 487 & 577 \\
\hline \multicolumn{2}{|c|}{ WGL-32100 } & 11.7 & 14.0 & 12.8 & 1010 & 1452 & 1231 & 756 & 511 & 633 \\
\hline \multicolumn{2}{|c|}{ Varalu } & 10.0 & 13.0 & 11.5 & 917 & 1146 & 1032 & 571 & 465 & 518 \\
\hline \multicolumn{2}{|c|}{ JGL-1470 } & 11.3 & 14.3 & 12.8 & 953 & 1352 & 1153 & 547 & 445 & 496 \\
\hline JGL-38 & & 12.0 & 13.0 & 12.5 & 1082 & 1226 & 1154 & 506 & 422 & 464 \\
\hline JGL-38 & & 11.0 & 13.0 & 12.0 & 1076 & 1249 & 1162 & 581 & 431 & 506 \\
\hline Mean & & 11.7 & 13.5 & 12.6 & 1039 & 1290 & 1165 & 573 & 449 & 511 \\
\hline & Treatments (T) & & 0.457 & & & 3.993 & & & 15.356 & \\
\hline C.D & Genotypes (G) & & 1.076 & & & 34.760 & & & 27.172 & \\
\hline$(5 \%)$ & T X G & & $\mathrm{NS}$ & & & 48.320 & & & 39.849 & \\
\hline
\end{tabular}


Table.6 The influence of nitrogen on grain yield $\left(\mathrm{Kg} \mathrm{ha}^{-1}\right)$ in rice genotypes

\begin{tabular}{|c|c|c|c|c|}
\hline \multirow{2}{*}{\multicolumn{2}{|c|}{ Genotypes }} & \multicolumn{3}{|c|}{ Grain yield $\left(\mathrm{Kg} \mathrm{ha}^{-1}\right)$} \\
\hline & & N 60 & N 120 & Mean \\
\hline \multicolumn{2}{|c|}{ WGL-14 } & 3200 & 4423 & 3811 \\
\hline \multicolumn{2}{|c|}{ BPT-5204 } & 4810 & 5036 & 4923 \\
\hline \multicolumn{2}{|c|}{ WGL-2395 } & 4976 & 5175 & 5076 \\
\hline \multicolumn{2}{|c|}{ DIVYA } & 4740 & 4856 & 4798 \\
\hline \multicolumn{2}{|c|}{ JGL-11727 } & 4741 & 4983 & 4862 \\
\hline \multicolumn{2}{|c|}{ POTHANA } & 4869 & 5046 & 4957 \\
\hline \multicolumn{2}{|c|}{ RNR-C-28 } & 4219 & 4402 & 4310 \\
\hline \multicolumn{2}{|c|}{ RNR-2354 } & 3148 & 4230 & 3689 \\
\hline \multicolumn{2}{|c|}{ RNR-2465 } & 3072 & 4072 & 3572 \\
\hline \multicolumn{2}{|c|}{ JGL-3855 } & 3750 & 4618 & 4184 \\
\hline \multicolumn{2}{|c|}{ NDLR-7 } & 3073 & 3798 & 3436 \\
\hline \multicolumn{2}{|c|}{ SUREKHA } & 2636 & 3458 & 3047 \\
\hline \multicolumn{2}{|c|}{ RNR-2458 } & 3847 & 4504 & 4175 \\
\hline \multicolumn{2}{|c|}{ MTU-1001 } & 5021 & 5364 & 5192 \\
\hline \multicolumn{2}{|c|}{ ERRAMALLELU } & 2923 & 3641 & 3282 \\
\hline \multicolumn{2}{|c|}{ BHADRAKALI } & 4821 & 5001 & 4911 \\
\hline \multicolumn{2}{|c|}{ JGL-1798 } & 4918 & 5141 & 5030 \\
\hline \multicolumn{2}{|c|}{ GODAVARI ISUKALU } & 4130 & 4772 & 4451 \\
\hline \multicolumn{2}{|c|}{ KAVYA } & 4720 & 4873 & 4797 \\
\hline \multicolumn{2}{|c|}{ MTU-1010 } & 5015 & 5338 & 5176 \\
\hline \multicolumn{2}{|c|}{ CHITTIMUTYALU } & 4144 & 4816 & 4480 \\
\hline \multicolumn{2}{|c|}{ WGL-32100 } & 3445 & 4697 & 4071 \\
\hline \multicolumn{2}{|c|}{ VARALU } & 2549 & 3275 & 2912 \\
\hline \multicolumn{2}{|c|}{ JGL-1470 } & 3649 & 4818 & 4233 \\
\hline \multicolumn{2}{|c|}{ JGL-3844 } & 3111 & 4399 & 3755 \\
\hline \multicolumn{2}{|c|}{ JGL-3828 } & 4094 & 4634 & 4364 \\
\hline \multicolumn{2}{|l|}{ Mean } & 3985 & 4591 & 4288 \\
\hline \multirow{3}{*}{$\begin{array}{c}\text { C.D } \\
(\mathbf{5 \%})\end{array}$} & Treatments $(\mathbf{T})$ & \multicolumn{3}{|c|}{73.546} \\
\hline & Genotypes (G) & & 108.66 & \\
\hline & T X G & & 163.04 & \\
\hline
\end{tabular}

The interaction between nitrogen levels and rice genotypes was highly significant for grain yield. Among the treatment combinations, highest grain yield of $5364 \mathrm{~kg}$ ha $^{-1}$ was recorded with $120 \mathrm{Kg} \mathrm{N} \mathrm{ha}^{-1}$ in MTU-1001, whereas lowest grain yields of $2548 \mathrm{~kg} \mathrm{ha}^{-1}$ was recorded in Varalu with application of $60 \mathrm{Kg} \mathrm{N} \mathrm{ha}{ }^{-1}$. The grain yield significantly increased with increasing nitrogen levels up to $120 \mathrm{~kg} \mathrm{~N} \mathrm{ha}^{-1}$. Nitrogen contributes to carbohydrate accumulation in culms and leaf sheaths during the pre-heading stage and in the grain during the ripening stage of rice (Bahmanyar and Ranjbar, 2007).

In conclusion, in the present study rice varieties responded well to higher levels of nitrogen. Among the nitrogen levels $120 \mathrm{Kg}$ 
$\mathrm{N} \mathrm{ha}^{-1}$ and rice genotypes MTU-1001 has recorded highest grain yield and lowest grain yield was recorded in Varalu with application of $60 \mathrm{Kg} \mathrm{N} \mathrm{ha}{ }^{-1}$. The adequate quantity of nitrogen at right time helped rice plants to promote the yield and also accumulation of nitrogen elements in rice productive organs and its distribution is an important process which determines the grain yield.

\section{Acknowledgement}

The present work carried out in Ph.D programme supported by assistance provided by Department of Science and Technology, INSPIRE Fellowship, Govt. of India and PJTSAU for the financial support.

\section{References}

Ashrafuzzaman, M., Islam, M.R., Ismail, M.R., Shahidullah, S.M and Hanafi, M.M. 2009. Evaluation of six aromatic rice varieties for yield and yield contributing characters. Int. J. Agri. Biol., 11: 616-620.

Bahmanyar, M.A., Ranjbar, G.A. 2007. Response of rice cultivar to rates of nitrogen and potassium application in field and pot conditions. Pakistan J. Biol. Sci., 10(9): 1430-1437.

Devi, G and Sumathi, V. 2011. Effect of nitrogen management on growth, yield and quality of scented rice under aerobic conditions. J. Res. ANGRAU, 39(3): 81-83.

Gosh, M., Swain, D.K., Jha, M.K and Tewari, V.K. 2013. Precision nitrogen management using chlorophyll meter for improving growth, productivity and nitrogen use efficiency of rice in subtropical climate. J. Agri. Sci., 5(2): 253-266.

Hassan, M.S., Abul Khair., Haque, M.M and Abdul Hamid. 2007. Photosynthetic characters, SPAD value and nitrogen use efficiency of traditional $A U S$ rice (Oryza sativa L.) cultivars. SAARC J. Agri., 5(2): 29-40.

Karim, D.U., Sarkar, M.N.A., Siddique, M.A., Khaleque Miah and Hasnat, M.Z. 2007. Variability and genetic parameter analysis in aromatic rice. Int. J. Sustainable Crop Production, 2(5): 1518.

Kim, B.K., Ko, K.J., Lee, K.J and Shin, H.T. 1993. Analysis of yield and its associated characters affected by planting density and fertilizer level in heavy-panicle Japonica rice. Korean $J$. Breeding, 31(1): 21-28.

Miah, M.N.H., Yoshida, T and Yomamoto, Y. 1997. Effect of nitrogen application during ripening period on photosynthesis and dry matter production and its impact on yield and yield components of semi dwarf indica rice varieties under water culture conditions. Soil Sci. Plant Nutri., 43(1): 205-217.

Panse, V.G. and Sukhatme, P.V. 1978. Statistical methods for agricultural works. Indian Council of Agri. Res., New Delhi. 145-150.

Ramesh, T., Sathiya, K., Padmanaban, P.K and Martin, J.M. 2009. Optimization of nitrogen and suitable weed management practice for aerobic rice. Madras Agri. J., 96(7-12): 344-348.

Ranjitha, S. 2011. Performance of Rice (Oryza sativa L.) cultivars and hybrids under different nutrient management practices in SRI. M.Sc. (Ag.) Thesis. Acharya N.G. Ranga Agricultural University, Hyderabad, India.

Sachiko, N., Kazunobu Toriyama and Yoshimichi Fukuta. 2009. Genetic variations in dry matter production and physiological nitrogen use efficiency in rice (Oryza sativa L.) varieties. Breeding Sci., 59: 269-276.

Samonte, S.O.P.B., Wilson, L.T and Mc 
Clung, A.M. 1998. Path analysis of yield and yield related traits of fifteen diverse rice genotypes. Crop Sci., 38: 1130-1136.

Sandhya Rani, K. 2012. Influence of nitrogen and weed management on growth and yield of aerobic rice. M.Sc. (Ag) Thesis. Acharya N.G. Ranga Agricultural University, Hyderabad, India.

Shahidullah, S.M., Hanafi, M.M., Ashrafuzzaman, M., Razi Ismail, $M$ and Salam, M.A. 2009. Phenological characters and genetic divergence in aromatic rice. African J. Biotechnol., 8(14): 3199-3207.

Sharma, P.K. and Masand, S.S. 2008. Fertilizer nitrogen economy, soil nutrient status, water use efficiency and rice productivity with real-time $\mathrm{N}$ management and organic residues under irrigated and rainfed situations. $J$. Indian Society of Soil Sci., 56: 167-173.

Sowmya, Ch. 2008. Studies on Integrated Nutrient Management under System of Rice Intensification (SRI). M.Sc. (Ag.) Thesis. Acharya N.G. Ranga Agricultural University, Hyderabad, India.
Suryaprabha, A.C., Thiyagarajan, T.M and Senthivelu, M. 2011. System of Rice Intensification principles on growth parameters, yield attributes and yields of rice (Oryza sativa L.). J. Agron., 1: 27-33.

Swain, D.K., Bhaskar, B.C., Krishnan, P., Rao, K.S., Nayak, S.K. and Rabindranath, D. 2006. Variation in yield, $\mathrm{N}$ uptake and nitrogen use efficiency of medium and late duration rice varieties. J. Agri. Sci., 1-15.

Thakur, A.K., Sreelatha Rath, Patil, D.U and Ashwani Kumar. 2011. Effects on rice plant morphology and physiology of water and associated management practices of the system of rice intensification and their implications for crop performance. Paddy Water Enviornm., 9: 13-24.

Zahid, A.M., Akhtar, M., Anwar, M and Adil Jamal. 2009. Genotypic and phenotypic correlation and path analysis in coarse grain rice. Proceedings of the Int. Seminar on Rice Crop, October 2-3. Rice Research Institute, Kala Shah Kau, Pakistan.

\section{How to cite this article:}

Rajesh, K., Ramesh Thatikunta, D. Saida Naik and Arunakumari, J. 2017. Effect of Different Nitrogen Levels on Morpho Physiological and Yield Parameters in Rice (Oryza sativa L.). Int.J.Curr.Microbiol.App.Sci. 6(8): 2227-2240. doi: https://doi.org/10.20546/ijcmas.2017.608.262 